\title{
Perancang Aplikasi M-Commerce Berbasis Android Sebagai Media Informasi dan Penjualan Kambing
}

\author{
Retno Waluyo', Zulia Karini², and Kharis Ardi Purnomo ${ }^{3}$ \\ ${ }^{1}$ Sistem Informasi, STMIK Amikom Purwokerto \\ 2,3 Teknik Informatika, STMIK Amikom Purwokerto \\ Jl. Letjen Pol Sumarto Watumas Purwanegara Purwokerto, \\ Banyumas 53123, Indonesia \\ ${ }^{1}$ waluyo@amikompurwokerto.ac.id ; ${ }^{2}$ zulia@amikompurwokerto.ac.id ; ${ }^{3}$ kharis.ardi@gmail.com
}

\begin{abstract}
Abstrak - Hewan Kambing merupakan salah satu hewan yang banyak diminati oleh masyarakat untuk keperluan upacara agama atau dikonsumsi, permintaan hewan kambing meningkat pada saat menjelang hari raya idul adha untuk keperluan qurban. Untuk mendapatkan hewan kambing pembeli mencari di pasar hewan yang hanya buka 2 kali dalam satu minggu. Adanya biaya operasional dan Calo menjadikan harga dipembeli menjadi mahal, kurangnya media untuk mengetahui informasi peternak kambing dan harga kambing belum ada menjadikan pembeli mendapatkan harga yang mahal. Tujuan penelitian ini membangun aplikasi m-commerce berbasis android sebagai media informasi dan penjualan kambing yang dapat mempertemukan antara pembeli dan peternak kambing, sehingga pembeli mendapatkan harga yang murah, terhindar dari Calo dan pembeli mendapatkan kambing yang berkualitas. Metode yang digunakan untuk pengembangan perangkat lunak menggunakan model sekuensial linier dengan tahapan analisis, desain, kode, dan pengujian. Hasil dari penelitian ini aplikasi m-commerce yang digunakan sebagai media informasi dan penjualan kambing, aplikasi m-commerce dilakukan pengujian Blackbox dinyatakan aplikasi ini dapat digunakan. Pengujian selanjutnya untuk mengetahui kelayakan oleh pengguna dengan kuesioner yang dibagikan kepada 30 orang responden, Hasil peritungan memperoleh rating scale sebesar $71,5 \%$, dengan demikian aplikasi sudah layak untuk digunakan.
\end{abstract}

Kata kunci - M-Commerce, android, sekuensial linier, penjualan.

\section{PENDAHULUAN}

Hewan Kambing merupakan salah satu hewan yang banyak diminati oleh masyarakat untuk keperluan upacara agama atau dikonsumsi, permintaan hewan kambing meningkat pada saat menjelang hari raya idul adha untuk keperluan qurban [1]. Pada tahun 2014 konsumsi daging segar per kapita mengalami peningkatan sebesar $6,65 \%$ [2].

Untuk mendapatkan hewan kambing pembeli mencari di pasar hewan, namun pembeli yang membutuhkan kambing hanya di hari tertentu saja dikarenakan pasar hewan hanya buka 2 kali dalam satu minggu.

Biaya operasional yang dikeluarkan oleh peternak untuk membawa kambing ke pasar dan adanya Calo dipasar hewan menjadikan harga yang ada dipasar menjadi naik, sehinga menjadikan petani mendapat keuntungan yang kecil [3].

Dari penelitian yang dilakukan oleh [4] disebutkan bahwa rata-rata biaya yang dikeluarkan untuk memasarkan seekor ternak domba jantan dari pedagang kecil sampai konsumen akhir adalah Rp. 128.813,38/ekor. Kemudian penelitian yang dilakukan oleh [5] diperoleh kesimpulan bahwa penambahan nilai pemasaran pada rantai pasok sebesar Rp. 200.000/ekor. Dari kedua penelitian tersebut ditemukan fakta bahwa pihak yang memeproleh keuntungan terbesar adalah calo.

Agar terhindar dari Calo, pembeli dapat membeli secara langsung kepada peternak, namun mengalami kesulitan karena kurangnya media informasi mengenai tempat peternak kambing. Selain itu, tidak adanya informasi harga kambing menjadi kendala pembeli untuk dapat membeli kambing dengan harga yang ideal serta untuk mencari hewan kambing yang berkualitas dengan perkiraan harga serta detail info kambing susah di dapatkan.

Indonesia merupakan salah satu negara dengan pengguna smartphone yang tinggi, Diprediksi pertumbuhan pengguna smartphone di 
indonesia pada tahun 2019 sebanyak 92 juta pengguna [6].

Dengan banyaknya pengguna smartphone berbasis android dapat digunakan untuk kegiatan jual beli atau pemasaran yang dikenal dengan $e$ commerce, adanya e-commerce menjadikan transaksi lebih mudah dan mengurangi biaya yang dikeluarkan [7]. Oleh pelaku usaha e-commerce bisa menjadi pilihan untuk melakukan proses jual beli, selain itu informasi yang ada bermanfaat bagi pelaku usaha [8]. Pemanfaatan internet di smartphone juga bisa digunakan untuk kegiatan bisnis atau disebut dengan m-commerce [9]. M-Commerce adalah sebuah alat untuk melakukan transaksi komersial dan membantu konsumen melakukan transaksi melalui perangkat internet tanpa kabel [10].

Adanya aplikasi m-commerce berbasis android memudahkan pelanggan untuk mengetahui informasi mengenai harga pangan sesuai dengan kebutuhan pengguna [11]. Selain itu dapat menjadi pendukung penjual melakukan proses jual beli serta memudahkan pembeli [12].

Dengan latar belakang diatas, penelitian ini memiliki tujuan membangun aplikasi m-commerce berbasis android sebagai media informasi dan penjualan kambing yang dapat memepertemukan antara pembeli dan peternak kambing, sehingga penjual dan pembeli terhindar dari Calo dan pembeli mendapatkan kambing yang berkualitas.

\section{METODE PENELITIAN}

Dalam penyusunan penelitian ini Pengumpulan data dilakukan dengan cara:

1. Wawancara (interview)

Wawancara dilakukan untuk memperoleh informasi secara langsung dai sumbernya. Wawancara dilakukan kepada penjual dan pembeli kambing di pasar Pasar hewan Kecamatan Batur sebanyak 30 responden.

\section{Pengamatan}

Pengamatan dilakukan untuk mengamati kegiatan yang berlangsung. Pengamatan dilakukan pada proses transaksi penjualan kambing.

3. Studi pustaka

Dalam hal ini mengumpulkan data-data yang sesuai permasalahan yang dihadapi dengan mengambil dari literatur yang relevan sebagai bahan referensi.

Pengembangan perangkat lunak menggunakan model sekuensial linier, model pengembangan perangkat lunak ini terdiri dari beberapa aktivitas-aktivitas yang dimulai dari analisis, desain, kode, pengujian dan pemerliharaan [13].

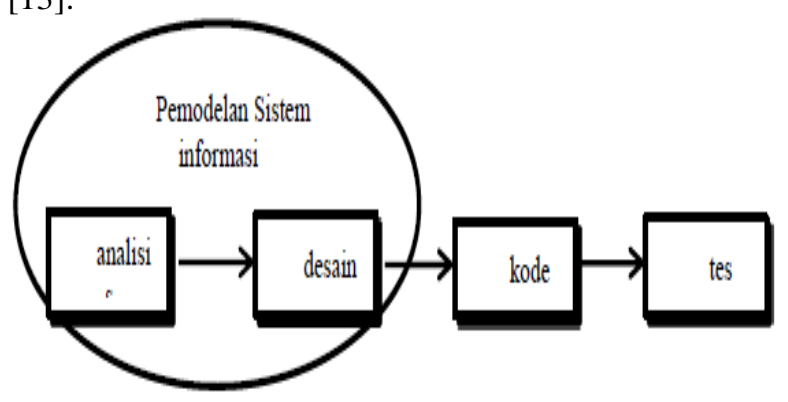

Gambar 1. Model Sekuensial Linier

A. Analisis Kebutuhan Perangkat Lunak

Kebutuhan dari sistem maupun perangkat lunak dikumpulkan dan didokumentasikan sesuai kebutuhan pelanggan, kemudian memahami domain informasi, tingkah laku, kinerja dan antarmuka diperlukan untuk membangun program.

B. Desain

Untuk menjaga kualitas perangkat lunak maka proses desain diperlukan sebelum melakukan pemunculan kode. pada proses desain berfokus pada struktur data, arsitektur perangkat lunak, representasi antarmuka dan algoritma

C. Kode

Desain yang sudah dibuat, agar bisa dipahami oleh mesin maka diterjemahkan kedalam bahasa mesin.

D. Tes / Pengujian

Pengujian diperlukan untuk mengetahui eror yang ada pada perangkat lunak setelah dilakukan koding, selain itu untuk memastikan hasil sudah sesuai dengan kebutuhan dari pelanggan.

\section{HASIL DAN PEMBAHASAN}

\section{A. Analisis}

Kebutuhan fungsional untuk memenuhi kebutuhan aplikasi sebagai berikut:

1. Kebutuhan masukan

Kebutuhan masukan yang diperlukan yaitu data pengguna dan data hewan yang diposting. 


\section{Kebutuhan proses}

Kebutuhan proses meliputi proses pemasukan data-data profil mengenai penjual, proses memasukan data hewan oleh penjual, proses memasukan data pengguna sebagai user.

3. Kebutuhan keluaran

Kebutuhan keluaran dari aplikasi ini mengenai data-data hewan yang akan dijual.

\section{Kebutuhan Antarmuka}

Kebutuhan antarmuka meliputi, Login, Pendaftaran, Halaman utama, Tampilan hewan yang dijual, Profil penjual.

Kebutuhan Non-Fungsional pada aplikasi ini adalah pengguna aplikasi sebagai penjual dan pembeli.

\section{B. Desain}

Tahap desain pada model sekuensial linear perancangan aplikasi, penelitian ini menggunakan UML (Unified Modelling Language) untuk memodelkan sistem yang peneliti buat, pada tahap pemodelan dengan UML terdiri dari macam-macam diagram UML antara lain use case diagram, sequence diagram, activity diagram, dan class diagram.

1. Use Case Diagram

Berikut ini adalah use case diagram pada aplikasi m-commerce sebagai media informasi dan penjualan kambing.

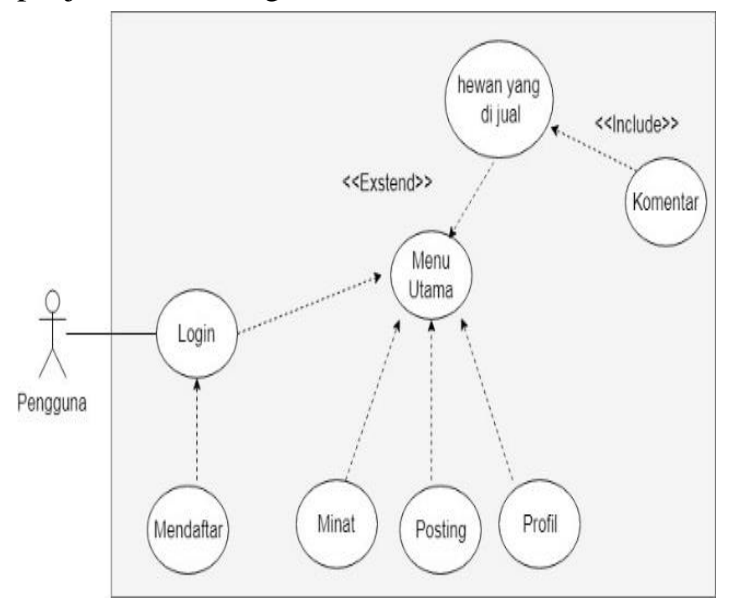

Gambar 2. Use Case Diagram

Gambar 2 menjelaskan proses alur aktivitas yang ada di aplikasi $m$-commerce yang memiliki satu aktor yaitu pengguna, pengguna dapat mengelola aplikasi seperti menambah postingan dan komen postingan untuk berinteraksi antara satu pengguna dengan pengguna yang lainya, pengguna dapat menambah, menghapus dan merubah postinganya sendiri tetapi tidak bisa menghapus ataupun merubah postingan pengguna lainya. Pengguna juga dapat menambahkan hewan yang dijual sebagai minat. Pengguna dapat melihat daftar postingan di halaman profile.

\section{Sequence Diagram}

Berikut adalah Sequence Diagram tambah minat untuk aplikasi $m$-commerce berbasis android.

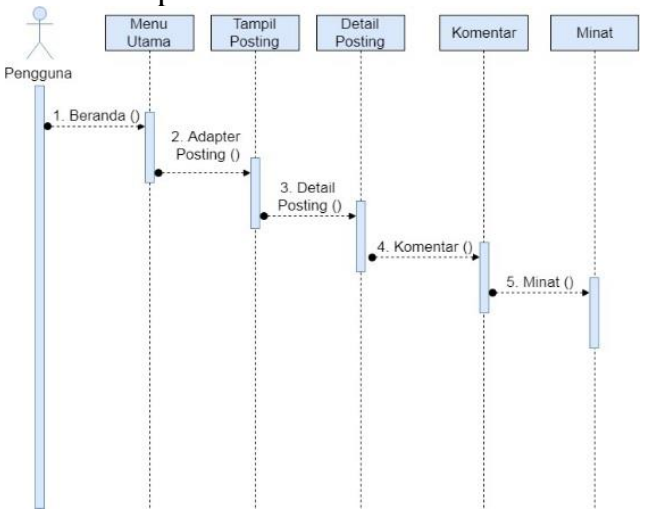

Gambar 3. Sequence Diagram Tambah Minat

Gambar 3. merangkan proses pengguna menampilan menu utama untuk melihat semua postingan, kemudian membuka layar postingan untuk melihat detail postingan, setelah itu pengguna menginputkan komentar dan selanjutnya akan mengirim ke database dan menampilkan di halaman minat.

3. Activity Diagram

Berikut adalah activity diagram menampilkan minat pada aplikasi m-commerce berbasis android

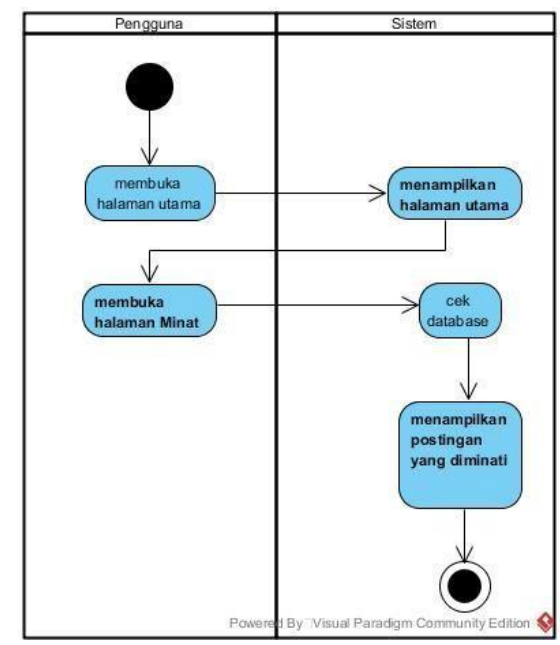

Gambar 4. Activity Diagram Tambah Minat

Gambar 4. menjelaskan aktivitas yang dilakukan pengguna untuk menampilkan postingan yang diminati, pengguna membuka menu utama 
kemudian sistem menampilkan halaman utama, selanjutnya pengguna membuka halaman minat dan sistem melakukan cek database jika ada postingan yang diminati maka akan menampilkan postingan di halaman minat.

4. ClassDiagram

Berikut ini adalah ClassDiagram pada aplikasi m-commerce berbasis anroid sebagai media informasi dan penjualan kambing.

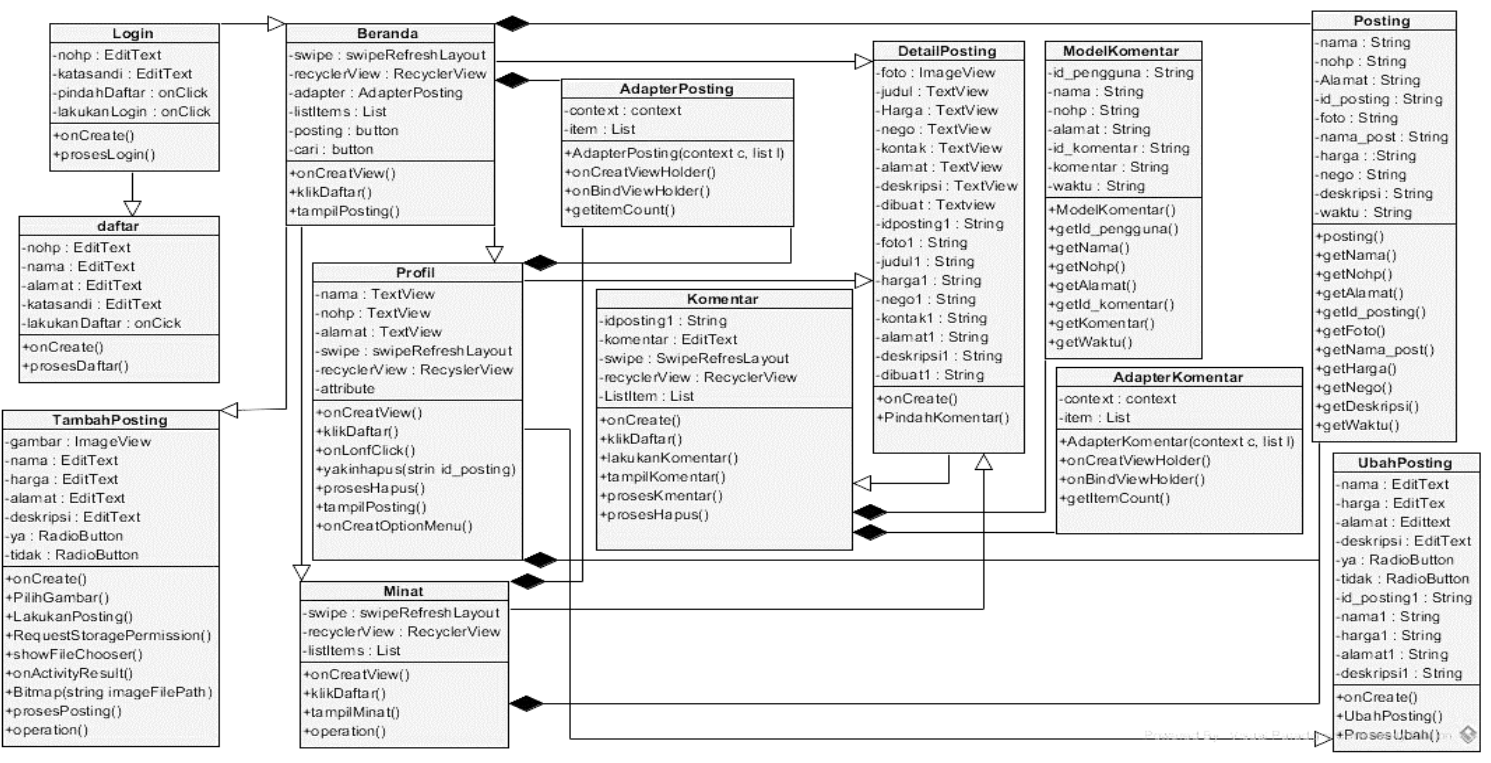

Gambar 5. ClassDiagram

\section{Pembuatan Kode Program}

Dalam pengodean yang dilakukan proses pembuatan web API kemudian dilanjutkan dengan konstruksi file xml dan membuat class java.

Halaman detail posting menampilan semua detail yang di posting oleh pengguna ataupun postingan pengguna lain, halaman detail posting terdapat button komentar, digunakan untuk menambahkan komentar posting.

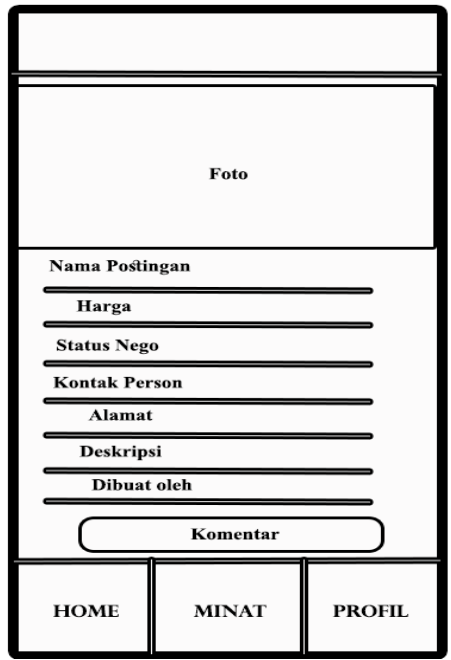

Gambar 6. Desain Halaman detail posting
D. Pengujian

1. Pengujian Sistem

Pada pengujian aplikasi menggunakan model Blackbox untuk pengujianya. Pengujian Blackbox bertujuan untuk mengetahui fungsional dengan cara melakukan input pada modul perangkat lunak sudah berjalan sesuai dengan proses yang diinginkan dengan melihat hasil output-nya [14] [15].

Tabel 1. Pengujian Blackbox

\begin{tabular}{|l|l|l|l|}
\hline No. & Kelas Uji & Butir Uji & Hasil \\
\hline 1. & Masuk & Verivikasi Data & Berhasil \\
\hline 2. & Mendaftar & Menambahkan Data & Berhasil \\
\hline 3. & Beranda & $\begin{array}{l}\text { Menampilkan semua data } \\
\text { postingan terbaru } \\
\text { dilengkapi info harga }\end{array}$ & Berhasil \\
\hline 4. & $\begin{array}{l}\text { Detail } \\
\text { Postingan }\end{array}$ & $\begin{array}{l}\text { Menampilkan detail } \\
\text { postingan yang dipilih }\end{array}$ & Berhasil \\
\hline 5. & Pencarian & Mencari postingan & Berhasil \\
\hline 6. & $\begin{array}{l}\text { Buat } \\
\text { Posting }\end{array}$ & $\begin{array}{l}\text { Menambahkan data } \\
\text { mengambil foto di galeri }\end{array}$ & Berhasil \\
\hline 7. & Minat & $\begin{array}{l}\text { Menampilkan postingan } \\
\text { yang diminati }\end{array}$ & Berhasil \\
\hline
\end{tabular}




\begin{tabular}{|l|l|l|l|}
\hline 8. & Profil & $\begin{array}{l}\text { Menampilkan profil } \\
\text { pengguna dan } \\
\text { menampilkan postingan } \\
\text { yang dilakukan oleh } \\
\text { pengguna }\end{array}$ & Berhasil \\
\hline 9. & Komentar & $\begin{array}{l}\text { Menambahkan komentar } \\
\text { postingan dan } \\
\text { menambahkan ke } \\
\text { minat }\end{array}$ & Berhasil \\
\hline 10. & $\begin{array}{l}\text { Hapus } \\
\text { Posting }\end{array}$ & Menghapus postngan & Berhasil \\
\hline 11. & $\begin{array}{l}\text { Ubah } \\
\text { posting }\end{array}$ & Mengubah postingan & Berhasil \\
\hline 12. & Hapus & Menghapus komentar & Berhasil \\
\hline 13. & Keluar & Keluar akun pengguna & Berhasil \\
\hline
\end{tabular}

Berdasarkan hasil pengujian Blackbox pada Tabel 1. diatas maka dapat disimpulkan bahwa semua sistem secara fungsional aplikasi berjalan sesuai apa yang diinginkan, sehingga aplikasi berhasil digunakan untuk mempermudah pembeli dalam mencari hewan kambing serta dapat langsung mengetahui harga dan alamat yang sudah di cantumkan oleh penjual. Sedangkan bagi penjual dapat digunakan sebagai media pemasaran hewan kambing.

2. Pengujian Aplikasi

Pada pengujian ini menggunakan kuesioner dengan responden sebanyak 30 orang. Kuesoiner dilakukan untuk mengetahui kelayakan menurut penggunaan aplikasi dengan variabel kemudahan, kelayakan dan kesesuaian kebutuhan. Rumus untuk perhitungan dengan skala likert sebagai berikut:

rumus index $\%=\frac{\text { total skor }}{\text { skor tertinggi }} \quad x \quad 100$ (1)

$$
\begin{aligned}
& =\frac{536}{750} \times 100 \\
& =71,5 \%
\end{aligned}
$$

Rating Scale adalah data mentah yang diperoleh berupa angka kemudian ditafsirkan dalam pengertian kualitatif [16].

Tabel 2. Rating Scale

\begin{tabular}{|c|c|}
\hline Nilai & Kriteria \\
\hline $81 \%-100 \%$ & Sangat Baik \\
\hline $61 \%-80 \%$ & Baik \\
\hline $40 \%-60 \%$ & Cukup \\
\hline $21 \%-39 \%$ & Tidak Baik \\
\hline $0 \%-20 \%$ & Sangat Tidak Baik \\
\hline
\end{tabular}

Dari hasil perhitungan kuesiner yang dilakukan didapatkan presentase nilai $71,5 \%$. Berdasarkan rating scale diatas tergolong dalam kriteria baik, sehingga aplikasi m-commerce sudah dapat digunakan untuk media informasi dan memasarkan hewan kambing.

E. Implementasi Antar Muka

Setelah melakukan tahap-tahap pengembangan sistem, selanjutnya aplikasi di implementasikan, tampilan pada saat aplikasi di implementasikan sebagai berikut:

1. Halaman beranda

Halaman beranda digunakan untuk menampilkan seluruh halaman dan terdapat link ke halaman tersebut yang dibutuhkan oleh bagi pembeli.

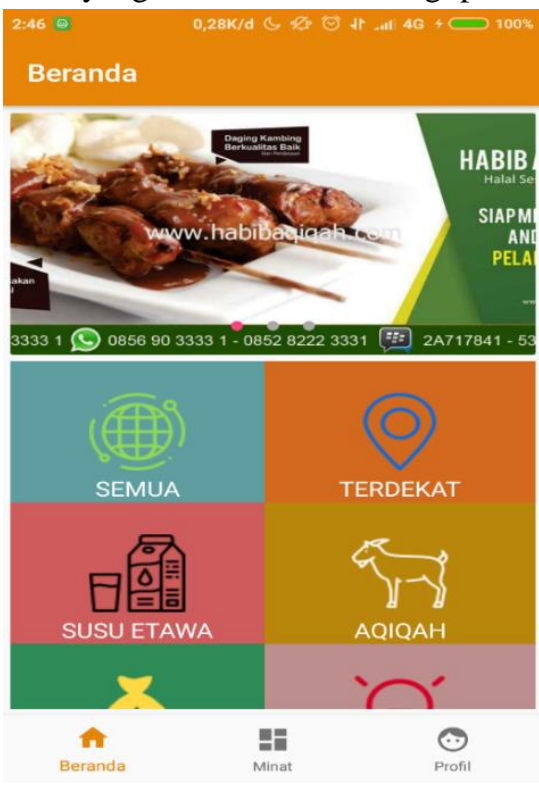

Gambar 7. Halaman beranda

2. Halaman Minat

Halaman minat digunakan untuk menampilkan daftar postingan hewan kambing yang diminati oleh pembeli.

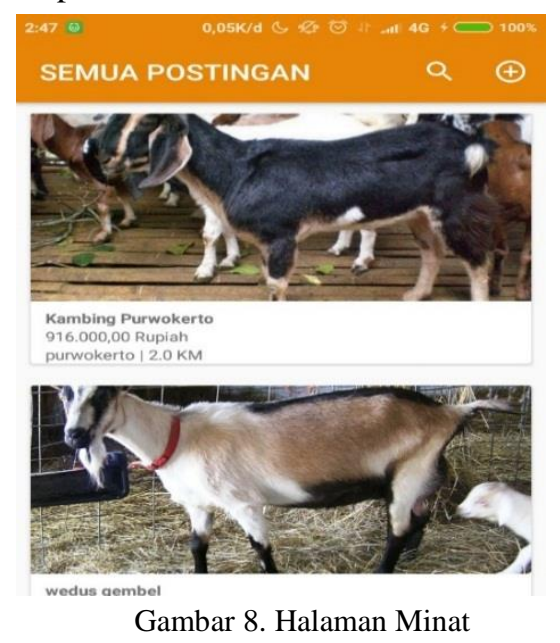

Gambar 8. Halaman Minat 
3. Halaman Detail Posting

Halaman posting digunakan untuk mengisi datadata hewan yang akan di posting oleh penjual, yang diperlukan seperti foto, nama posting, harga, status nego, alaman, dan deskripsi hewan.

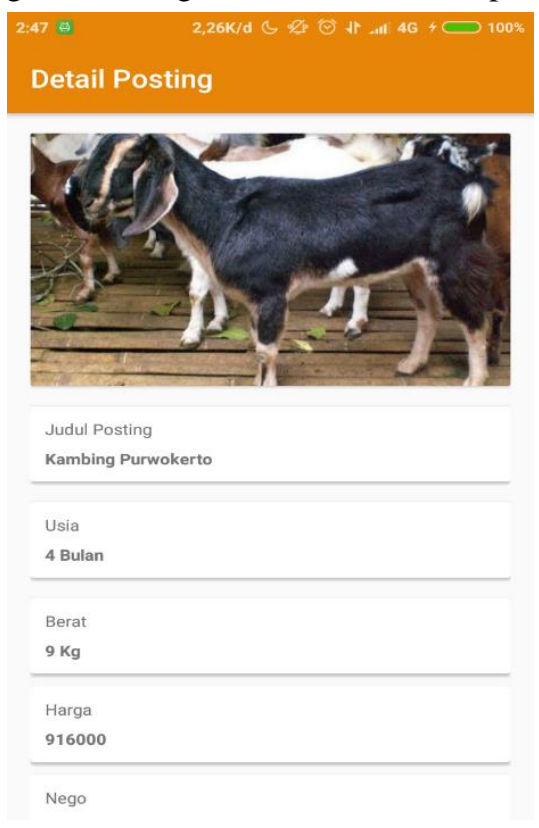

Gambar 9. Halaman Detail Psoting

\section{KESIMPULAN DAN SARAN}

Telah dibuat aplikasi $m$-commerce berbasis android sebagai media informasi dan penjualan kambing yang dapat mempertemukan antara pembeli dan peternak sehingga dapat terhindar dari calo dan mendapatkan harga yang murah. Setelah dilakukan pengujian blackbox, semua sistem secara fugnsional berjalan, sehingga dinyatakan aplikasi ini dapat di gunakan untuk mempermudah pembeli yang tidak mengetahui tempat penjualan hewan kambing dan informasi harga hewan kambing. hasil perhitungan kuisioner yang dilakukan didapatkan prosentase nilai $71,5 \%$ tergolong dalam kriteria baik, dengan demikian sudah layak untuk digunakan.

\section{REFERENSI}

[1] A. Firman, L. Herlina, M. Paturochman, and M. M. Sulaeman, "Penentuan Kawasan Unggulan Agribisnis Ternak Domba Di Jawa Barat," J. Pemikir. Masy. Ilm. Berwawasan Agribisnis, vol. 4, no. 1, pp. 111-125, 2018
E. Wahyudi, G. Ciptadi, and A. Budiarto, "Studi Kasus Tingkat Pemtotongan Kambing Berdasarkan Jenis kelamin, Kelompok Umur dan Bobot Karkas Di Tempat Pemotongan Hewan Kota Malang," J. Trop. Anim. Prod., vol. 18, no. 1, pp. 6976, 2007.

[3] A. Elysia, I. Darmawan, and M. A. Hasibuan, "Perancangan E-Commerce Angon Untuk Pelaku Peternak Berbasis Marketplace Untuk Meningkatkan Penjualan (Modul Penjualan)," in $e$ Proceeding of Engineering, 2016, vol. 3, no. 2, pp. 3143-3148.

[4] B. Wibowo, S. Rusdiana, and U. Adiati, "Pemasaran Ternak Domba Di Pasar Hewan Palasari Kabupaten Indramayu," Agriekonomika, vol. 5, pp. 85-93, 2016.

[5] I. M. Budiarsana, B. Wibowo, and D. Priyanto, "Produktivitas dan Rantai Pasok Ternak Kambing dan Domba ( KADO ) Studi Kasus di Kabupaten Tegal," J. Ilmu Ternak, vol. 16, pp. 35-42, 2016.

[6] I. Bestari and Nurdasila, "Pengaruh citra merek dan kewajaran harga terhadap loyalitas merek dengan kepuasan pelanggan sebagai pemediasi pada pengguna produk apple di kota banda aceh," J. Ilm. Mhs. Ekon. Manaj., vol. 2, no. 3, pp. 86-94, 2017.

[7] S. M. Maulana, H. Susilo, and Riyadi, "Implementasi E-commerce Sebagai Media Penjualan Online (Studi Kasus Pada Toko Pastbrik Kota Malang)," J. Adm. Bisnis, vol. 29, no. 1, pp. 1-9, 2015.

[8] Julisar and M. Eka, "Pemakaian ECommerce untuk Usaha Kecil dan Menengah Guna Meningkatkan Daya Saing," ComTech Comput. Math. Eng. Appl., vol. 4, no. 2, pp. 638-645, 2013.

[9] A. B. Arief, "Aplikasi M-Commerce Berbasis Android Pada Toko 'Fani Bags,", J. Sisfokom (Sistem Inf. dan Komputer), vol. 3, 2014.

[10] I. Clarke III, "Emerging value propositions for m-commerce," J. Bus. Strateg., vol. 25, no. 2, pp. 41-57, 2008.

[11] E. Kojongian, H. F. Wowor, and S. D. S. Karouw, "Sistem Informasi Komoditas Pasar di Kota Manado Berbasis Android," E-Journal Tek. Inform., vol. 12, no. 1, 2017.

[12] A. D. Riyanto and K. Ma'arif, “Aplikasi MCommerce Berbasis Android Pada Zona Komputer Banjarnegara," Telematika, vol. 9, no. 1, pp. 67-77, 2016.

[13] R. S. Pressman, Rekayasa Perangkat Lunak Buku I. Yogyakarta: Andi, 2002.

[14] R. S. Pressman, Rekayasa Perangkat Lunak: Pendekatan Praktisi (Buku Satu). 
Jurnal CoreIT, Vol.4, No.1, Juni 2018

ISSN 2460-738X (Print)

ISSN 2599-3321 (Online)

Yogyakarta: Andi, 2010.

[15] M. Muslihudin and oktafianto, Analisis dan Perancangan Sistem Informasi Menggunakan Model Terstruktur dan UML. Yogyakarta: Andi, 2016.

[16] Sugiyono, Metode Penelitian Kuantitatif, Kualitatif, dan $R \& D$. Bandung: Alfabeta, 2012. 